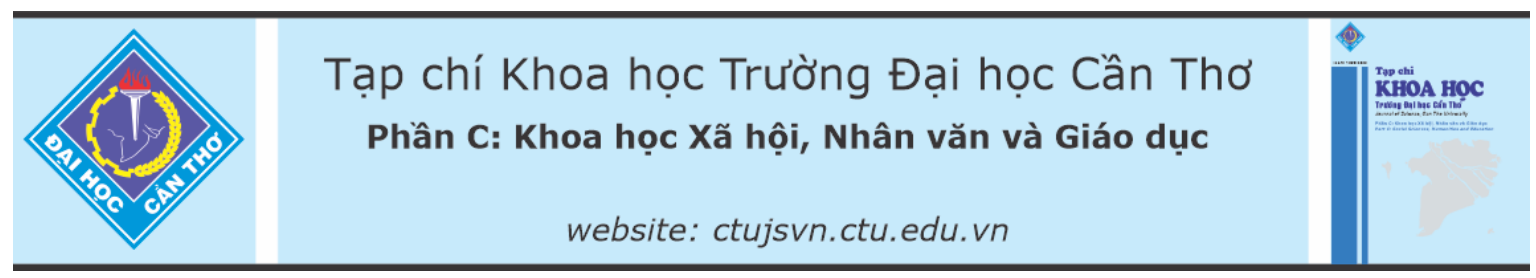

DOI:10.22144/ctu.jvn.2021.192

\title{
BIỂU TƯợNG THIÊN THAI TRONG VĂN HỌC TRUNG ĐẠI TRUNG HOA VÀ VIẸT NAM TỪ GÓC NHÌN CỦA TINH THẦ SINH THÁI LÃO - TRANG
}

\author{
Doãn Thị Huế* \\ Truờng Trung học cơ sở Phú Mỹ, Quận Bình Thạnh, Thành phố Hồ Chí Minh \\ *Nguò̀i chịu trách nhiệm về bài viết: Doãn Thị Huế (email: nguyenthaonguyen123@gmail.com)
}

\section{Thông tin chung:}

Ngày nhận bài: 09/09/2021

Ngày nhận bài sủa: 22/10/2021

Ngày duyệt đăng: 25/12/2021

\section{Title:}

The symbol of fairyland in Chinese and Vietnamese medieval literature from perspective of Lao - Chuang ecological spirit

\section{Tù khóa:}

Biểu tuợng thiên thai, sinh thái Lão - Trang, văn hoc Trung Hoa và Việt Nam

\section{Keywords:}

The symbol of fairyland, LaoChuang ecological, Chinese and Vietnamese literature

\begin{abstract}
The philosophy of Lao Tzu-Chuang Tzu (expressed in Ethical sutra and Nanhua sutra) was originally imbued by the ecological spirit of the Eastern through the ancient times. This philosophy provides us with interesting suggestions when researching the relations of natural world and humanity that relates to fairyland - a symbol of culture, unique ancient literature that has appeared in the Chinese and Vietnamese medieval literature. In the spirit of this ecology from Lao-Chuang theory, we will focus on understanding the fairyland symbol that includes two main meanings: the symbol of fairyland - where the consciousness conserver about original ecologic belongs to and the symbol of fairyland - where humans living in harmony with nature. The study about the fairyland symbol from this point of view would help finding out more about the new values of Chinese and Vietnamese medieval literature, also advancing the consciousness about the role of nature in human lives, and proving that Lao - Chuang theory is an philosophy ancient but not out of date.
\end{abstract}

\section{TÓM TÁT}

Tur tưởng Lão - Trang (thể hiện qua Đạo đức kinh và Nam hoa kinh) vốn mang đậm tinh thần sinh thái phương Đông thời cổ đại. Triết thuyết này cung cấp cho chúng ta những gợi ý thú vị khi khai thác mối quan hệ giữa tụ nhiên và con nguời gắn liền với thiên thai - một biểu tương văn hoá, văn hoc cổ xua độc đáo xuất hiện trong văn học trung đại Trung Hoa và Việt Nam. Trên cơ sở tinh thần sinh thái trong học thuyết Lão - Trang, chúng tôi sẽ tập trung khai thác biểu tuợng thiên thai gắn với hai ý nghĩa lớn: biểu tuợng thiên thai - nơ luu giữ tâm thức về một hệ sinh thái nguyên thuý và biểu tuoơng thiên thai - nơ con nguò̀i học cách thích nghi với tư nhiên. Việc nghiên cứu biểu tượng thiên thai tù góc nhìn này sẽ giúp phát hiện thêm các giá trị mói của văn học trung đại Trung Hoa và Việt Nam, đồng thời giúp nâng cao ý thức về vai trò quan trọng của tụ nhiên đối với đời sống con nguời và chứng minh rằng học thuyết Lão - Trang là một học thuyết cổ xưa nhưng không lỗi thòit.

\section{1. ĐặT VẤN ĐỀ}

Tư duy chủ biệt, duy lý khiến cho nền văn minh phương Tây từ rất sớm đã đề cao con người, coi con người là trung tâm sáng tạo ra vũ trụ, tự nhiên. Điều này thể hiện rõ ở việc người phương Tây cổ xưa xây dựng thế giới và vườn Địa Đàng trong sách Sáng thế $k y ́$ với cái nhìn mặc định rằng tự nhiên là sản phẩm 
sáng tạo của Thiên Chúa, Thiên Chúa cho phép con người quyền thống trị đối với cá dưới biển, chim trên trời cùng mọi sinh vật di chuyển nơi mặt đất. Trong khi đó, xuất phát từ đặc điểm loại hình văn hoá gốc nông nghiệp với tư duy chủ toàn, trọng tình, người phương Đông từ rất sớm đã có tinh thần sùng thượng tự nhiên. Điều này được thể hiện rất rõ trong tín ngưỡng thờ cúng các vị thần tự nhiên như thần sấm, thần gió, thần sông, thần núi... Tuy nhiên, tinh thần sinh thái của người phương Đông thời kỳ này là tư tưởng mang tính "tự phát" và nó chỉ thực sự trở thành "tự giác" khi bắt gặp ý thức thuần nhiệm tự nhiên của Lão - Trang kề từ thế kỷ thứ IV trước công nguyên trở về sau. Điều đặc biệt là ý thức đề cao tự nhiên ấy đã được các văn nhân trung đại Việt Nam chuyển hoá, kết tinh ở biểu tượng thiên thai.

\section{GIẢI QUYÊT VẤN ĐỀ}

\subsection{Khái quát về biểu tượng thiên thai trong văn học trung đại Trung Hoa và Việt Nam}

Thiên thai là khái niệm rất quen thuộc đồng thời cũng rất huyền bí trong đời sống văn hoá, đặc biệt là ở các nước Á Đông (các nước nằm trong vùng ảnh hưởng của văn hoá Hán). Về tên gọi thiên thai, nguồn gốc của nó thực ra xuất phát từ "tên của một dãy núi có thật trên bản đồ địa lý Trung Quốc, nằm gần biển thuộc huyện Thiên Thai, tỉnh Triết Giang. Thiên Thai là dãy núi có địa thế cheo leo, hiểm trở và theo truyền thuyết của Trung Quốc thì đó là cõi tiên ở" (Trần Trúc Lâm, 2013). Trong văn học, sách Suu Thần ký của Can Bảo là cuốn sách có chứa đựng sáng tác sớm nhất liên quan đến núi Thiên Thai gắn với câu chuyện gặp tiên của hai chàng Lưu Thần, Nguyễn Triệu (Luu Nguyễn nhập Thiên Thai). Dựa vào sáng tác của Can Bảo, sau này, nhiều văn nhân thi sĩ cũng có những sáng tác liên quan đến cõi thiên thai cùng môtip như vậy. Tiêu biểu phải kể đến là Thiên Thai phỏng ẩn luc (trích Tiễn đăng tân thoại của Cù Hựu) ở đời nhà Thanh (Trung Hoa). Từ những sáng tác đó, thiên thai đi vào văn học của các nước trong vùng văn hoá chữ Hán và nó không còn là cái tên gắn liền với một vùng đất cụ thể của Trung Hoa nữa mà đã trở thành một biểu tượng nổi tiếng trong sáng tác thời trung đại (và cả hiện đại) gắn với tiên giới.

Ngoài thiên thai, trong văn học còn có những khái niệm khác như tiên cảnh, bồng lai, đào nguyên... cũng dùng để chỉ những vùng đất tiên mơ mộng. Thực chất, đây là những khái niệm tương đồng với thiên thai. Vì vậy, trong bài viết này, cõi thiên thai được hiểu là tên gọi chung cho các vùng tiên cảnh, bồng lai, đào nguyên. Trong các tác phẩm văn học cổ điển Trung Hoa và Việt Nam, nơi đó “có khi là nơi tiên ở giống như tiên cảnh, bồng lai; cũng có khi nó lại là một vùng đất tách biệt bên ngoài không - thời gian của trái đất tương tự như đào nguyên. Dù tên gọi khác nhau nhưng thực chất cõi tiên, bồng lai, đào nguyên hay thiên thai cũng đều là biểu tượng về một vùng đất lãng mạn cổ xưa, một chốn thần tiên hạnh phúc lý tưởng của người phương Đông" (Nguyễn Kim Châu, 2020).

Ước mơ của con người về một chốn thần tiên thực chất đã có từ thời thượng cổ và được ghi chép một cách phong phú trong các tài liệu văn học, lịch sử, tôn giáo... Ở phương Đông, trong tư duy của con người cổ đại, những vùng đất như vậy đã xuất hiện từ rất lâu, trong quan niệm về thế giới, đặc biệt là trong triết thuyết Phật giáo (gắn liền với cõi Cực Lạc) và triết thuyết Đạo giáo (gắn liền với ghi chép về những vùng đất nơi con người và thần nhân sinh sống như nước Hoa Tư Thị trong Xung hu chân kinh của Liệt Tử, núi Cô Dạ trong Nam hoa kinh của Trang Tử...). Từ đó, thiên thai trở thành một thứ "ký ức văn hoá" (chữ dùng của $\mathrm{J}$. Lotman) và đi xuyên qua các thời đại. Lúc này biểu tượng thiên thai được coi là trung gian, mang trong mình sự hoà trộn giữa "ký ức văn hoá" và văn hoá thời đại. Nằm trong vùng ảnh hưởng của văn hoá Hán, văn học Việt Nam đã tiếp thu biểu tượng này một cách sáng tạo trong các tác phẩm, đặc biệt là văn học trung đại. Do đó, khi khám phá biểu tượng thiên thai trong văn học trung đại Việt Nam, ngoài những ý nghĩa cổ xưa, ta còn thấy xuất hiện những ý nghĩa mới được sản sinh từ môi trường văn hoá Việt Nam thời trung đại. Việc lặp đi lặp lại và có sự lưu truyền từ thế hệ này sang thế hệ khác, từ những huyền thoại cổ xưa cho đến sáng tác nghệ thuật thời nay cho thấy bản chất phổ quát bền vững của biểu tượng thiên thai. Chính vì vậy, khám phá biểu tượng thiên thai cũng chính là cách để chúng ta hiểu hơn về thế giới tâm hồn không phải của cá nhân mà của người phương Đông từ xa xưa.

\subsection{Dấu ấn của tinh thần sùng thượng tự nhiên trong tư tưởng Lão - Trang}

Khác với Nho giáo ở chỗ chỉ quan tâm vai trò của con người đối với việc cải tạo thế giới, xây dựng xã hội, triết thuyết Lão - Trang chủ trương kéo con người trở về với cội nguồn tự nhiên, tìm lại thiên căn bằng lẽ sống hài hòa với tự nhiên, xuất phát từ quan niệm phong phú và phức tạp về "Đạo". Trong Đạo đức kinh, từ việc coi "Đạo" là bản thể, là cội nguồn có tính bao trùm mọi sự tồn tại "Đạo sinh ra một, một sinh ra hai, hai sinh ra ba, ba sinh ra vạn vật" (Đạo sinh nhất, nhất sinh nhị, nhị sinh tam, tam sinh 
vạn vật) (Lão Tử, 2021), Lão Tử đã đề xướng học thuyết "Đạo tự nhiên". Theo đó, ông hình dung con người như một phần tử trong tập hợp, một bộ phận trong chuỗi liên kết của tự nhiên, vận động theo quy luật của tự nhiên, của "Đạo". Từ quan niệm đó, Lão Tử đã đề xướng những tiêu chuẩn ứng xử của nhân sinh: muốn tồn tại, con người phải biết thuận theo lẽ tự nhiên, không làm những điều tổn hại đến tự nhiên "Người phải theo đất; đất theo trời; trời theo Đạo; Đạo theo tự nhiên" (Nhân pháp địa, dịa pháp thiên, thiên pháp Đạo, Đạo pháp tư nhiên) (Lão Tử, 2021). Coi trọng tự nhiên ở việc gắn liền với bản tính vốn có của vạn vật khi chưa bị con người tác động vào, ông đề cao cái đẹp thuần khiết của tự nhiên như "gỗ chưa qua tay người”, bởi vẻ đẹp đó chính là vẻ đẹp tự thân, "một sự thể hiện sinh động nhất quy luật tồn tại và phát triển của vạn vật theo căn tính tự nhiên" và nó "nằm ngoài sự chi phối bởi ý thức chủ quan của con người" (Nguyễn Kim Châu, 2020). Đồng thời, Lão Tử kêu gọi con người "quay về với sự chất phác và chân thực” (phản phác chân quy). Tuy chưa trực tiếp đề cập khái niệm "tự nhiên cảnh vật", song có thể nói Lão Tử là người tích cực nhất trong việc đề cao thế giới tự nhiên ở thời kỳ này.

Kế thừa tư tưởng của Lão Tử, Trang Tử - người học trò xuất sắc của ông, cũng đề cao tự nhiên với quan niệm "Khi chưa có trời đất, đã có đạo rồi. Đạo sinh ra quỷ, sinh ra đế, sinh ra trời, sinh ra đất" (Trang Tử, 2021). Ông cho rằng "Biết được chỗ làm của trời là biết thuận theo cái lẽ tự nhiên của trời đất mà sống" và ông tha thiết kêu gọi con người hãy phá bỏ mọi trang sức đẽo gọt, giả tạo để trở về với sự thuần phác, tự nhiên (điêu trác phúc phác) và đề xướng chủ trương "tiêu dao" cũng như xây dựng hình mẫu "chân nhân" gắn liền với việc cảm thụ thiên nhiên. Chủ trương sống hoà hợp cùng tự nhiên của học thuyết Lão - Trang hoà vào tinh thần sùng thượng tự nhiên trong tâm thức dân gian đã mang đến một trải nghiệm thẩm mỹ phương Đông: trở về cội nguồn mỗi khi con người đứng trước thế giới tự nhiên. Tâm thế ấy thường gắn liền với những hành trình ngược chiều của con người, đặc biệt là các ẩn sĩ: rời bỏ nền văn minh nhân tạo để quay về với thế giới tự nhiên, quay về "nhà" của mình. Với tư cách là một triết thuyết in đậm dấu ấn tâm hồn và trí tuệ sinh thái phương Đông cổ đại, học thuyết Lão Trang đã giúp biểu tượng thiên thai trong các tác phẩm chịu ảnh hưởng của hệ tư tưởng này chuyển tải những thông điệp sâu sắc về việc đề cao vẻ đẹp thuần khiết và cuộc sống giản dị, hoà hợp với tự nhiên.

\subsection{Biểu tượng thiên thai - nơi lưu giữ tâm thức về một hệ sinh thái nguyên thuỷ}

Từ buổi bình minh của lịch sử, cuộc sống hái lượm, săn bắn, nương náu vào núi rừng đã gắn kết con người nguyên thuỷ với tự nhiên. Chính vì vậy, trong tâm thức của con người, những hình ảnh về những núi rừng hoang sơ với hệ sinh thái khoẻ mạnh, không có sự tác động và xâm chiếm của con người vẫn cứ lưu đọng mãi, nhất là trong văn hoá, văn học. Tâm thức đó đã hoà quyện với tinh thần sinh thái Lão - Trang, cho ra đời biểu tượng thiên thai gắn liền với hình ảnh núi rừng nguyên sinh thuần khiết cùng hệ động - thực vật phong phú.

Không khó để thấy được điều đó khi ta hệ thống các tác phẩm viết về chốn tiên cảnh, thiên thai, đào nguyên và nhận thấy ở đó cứ trở đi trở lại hình ảnh của những khu rừng rậm, những vùng núi non xa xôi, cách biệt thế giới con người. Ở văn học Trung Hoa, từ núi Cô Dạ có thần nhân sinh sống trong Nam hoa kinh đến những dãy núi trải dài như Nam sơn kinh, Tây sơn kinh, Đại hoang nam kinh... do các vị thần núi cai quản với rất nhiều loài chim, thú, kỳ hoa dị thảo trong Son hải kinh; từ núi Thiên Thai hiểm trở trong Luu Nguyễn nhập Thiên Thai đến núi Nam Sơn nơi tộc Bàn Hồ sinh sống trong truyện Bàn Hồ (Suu thần ký); từ khu rừng đào bạt ngàn thăm thẳm nơi đầu nguồn trong Đào hoa nguyên ký, đến vùng núi Lâm Hải nước Đông Ngô với những rắn chúa khổng lồ có hình thù con người trong truyện Rắn trắng rắn vàng (Sưu thần hậu ký)... đều mang những đặc điểm của một khu rừng tự nhiên cổ xưa tươi tốt, với hệ sinh thái phong phú.

Kế thừa tư tưởng Lão - Trang và tinh thần của văn học Trung Hoa đi trước, trong sáng tác của các văn nhân trung đại Việt Nam, hình tượng những khu rừng, đặc biệt là những khu rừng nguyên sinh cổ xưa cũng trở đi trở lại. Trong đó, có những vùng núi rừng sâu thẳm gắn với cõi thiên thai hiện lên thật sống động như núi Hoa Điệp "ngang dọc khoảng bốn mươi dặm, um tùm cây cối, bốn mùa đầy hoa" (Duyên la nước Hoa - Lê Thánh Tông); non tiên cao vút nghìn trượng sừng sững "sóng nước bao quanh" (Chuyện Tù̀ Thức lấy vợ tiên - Nguyễn Dữ); vùng núi $\mathrm{Na}$ "cao chót vót", "quạnh vắng, đất thẳm rừng sâu, chim núi kêu ran, muông rừng chạy quẩn", "bụi trần không bén tới, chân người không bước tới”, "dây leo, cành rậm lấp mất cả lối đi” (Chuyện người tiều phu ở núi $N a$ - Nguyễn Dữ); vùng núi lạ "cây cỏ xanh tươi" trên đảo tiên giữa biển hay vùng rừng núi, cồn đảo "chân người không đặt tới bao giờ" (trong truyện Tiên trên đảo và Động núi giữa biểnVũ Trinh)... Đặc điểm chung của các vùng sinh thái 
này là đều nằm biệt lập, xa cách với thế giới của con người, đồng thời, bên trong nó là một hệ môi sinh hoang dã, trù phú được bao bọc, tiếp dưỡng.

Gắn với hình tượng những khu rừng nguyên sinh này không thể thiếu đi một yếu tố quan trọng, đó là nước. Ta có thể dễ dàng nhận thấy điểm chung của nước trong hệ sinh thái thiên thai là nguồn cội cấu thành, dưỡng nuôi, bảo bọc cho hệ sinh thái rừng. Trong đó, nước xuất hiện dưới các dạng thức tự nhiên, phong phú như biển, sông, suối, ao, hồ, đầm, lạch, khe... Nước tạo nên chốn non tiên giữa cửa bể Thần Phù với đặc tính "không cố định mà bồng bềnh, tan hợp theo sóng" trong Chuyện Tù̀ Thức lấy $v o ̛$ tiên của Nguyễn Dũ̃. Nước cấu thành các đảo tiên hay động tiên nằm giữa biển khơi trong các sáng tác của Vũ Trinh, Phạm Đình Hổ. Núi Hoa Điệp vương quốc loài bướm trong Duyên lạ nước Hoa của Lê Thánh Tông cũng gắn liền với hình ảnh một con suối lớn rì rào bao quanh nó, chắn ngang trước mặt, cản trở những người muốn xâm nhập vào vùng đất thiêng này. Những vực nước sâu, những đầm lầy nguyên sơ kỳ lạ, linh thiêng như sông Dùng, đầm Đông Liệt trong truyện Sông Dùng của Phạm Đình Hổ được bao phủ chập chùng bởi nhiều lớp núi non hiểm trở cũng là không gian sống và sinh sôi, nảy nở của nhiều loài vật kỳ lạ. Vừa là nguồn cội cấu thành hệ môi sinh hoang dã cõi thiên thai, có chức năng bao bọc chúng tránh khỏi sự xâm phạm của con người, nước vừa như người mẹ dưỡng nuôi vạn vật, để chúng được sinh sôi sum suê. Nhờ đó, hệ thực vật nơi đây luôn trù phú với "hoa cỏ tươi tốt rậm rạp" che khuất cả lối đi (Động núi giữa biểnVũ Trinh), "um tùm cây cối, bốn mùa đầy hoa" (Duyên lạ nước Hoa - Lê Thánh Tông); lại có cả các loài "cỏ lạ hoa kỳ" (Chuyện Tù̀ Thức lấy vọ tiên Nguyễn Dữ), "những quả đào lớn bằng cái đấu" (Thành Đạo Tứ - Phạm Đình Hổ), "những bàn đào ba ngàn năm khai hoa, ba ngàn năm kết quả" (Gặp tiên ở Hồ Lãng Bạc - Lê Thánh Tông)...

Ngoài chim loan, chim phượng, chim hạc hay xuất hiện trong thần thoại phương Đông, gắn với thế giới hoang sơ này còn là các loài thú hình thù kỳ dị, to lớn, dữ tợn như rắn chúa Vương Kính Tử “mình dài năm trượng, mào vàng, miệng đỏ, râu xanh, vảy trắng" (Truyện Giếng Việt - Trần Thế Pháp), những loài thuỷ tộc "vảy rồng mồm giải, mặt thú thân xà, nổi chìm lền xuống nhanh như mây bay" (Chuyện lạ nhà thuyền chài - Lê thánh Tông)... Bên cạnh đó, còn có những con vật hình dáng nhỏ bé mà kỳ quái "quây lượn như rồng", "chạy bon bon như ngựa", "tuy chỉ bằng đầu ngón tay mà vảy, sừng, lông, cánh, tai, mắt, chân, tay, con nào rõ ra con ấy" (Chuyện lạ nhà thuyền chài - Lê Thánh Tông) rồi có cả những đàn bướm vài vạn con mỗi lần bay lên thì "rợp cả góc trời" (Duyên lạ nước Hoa - Lê Thánh Tông). Thậm chí, ở nơi rừng sâu núi thẳm không người đặt chân tới, có nhiều loài sống lâu năm nên thành tinh, có khả năng biến hoá như tộc bướm ở núi Hoa Điệp (Duyên la nước Hoa - Lê Thánh Tông), những con vượn và cáo có thể hoá lốt người (trong Chuyện bũa tiệc đêm ở Đà Giang - Nguyễn Dữ), cá hoá thành tiên nữ (Chuyện lạ nhà thuyền chài - Lê Thánh Tông), những loài thuồng luồng vuốt ngắn linh thiêng hoá thần phù trợ cho con người (Sông Dùng - Phạm Đình Hổ)... Chúng cũng biết yêu, ghét, biết ơn nghĩa, sống biết đấu tranh, yêu chuộng tự do theo bản năng thiên tính. Hình thù của chúng có thể là dữ tợn, quái dị trong quan niệm thẩm mỹ của con người, nhưng ở góc nhìn sinh thái, đó là căn tính tự nhiên của các loài vật trong hệ sinh thái nguyên thuỷ hoang sơ còn đầy rẫy những bí ẩn thẳm sâu mà con người không nắm bắt hết được. Hình tượng này cũng xuất phát từ quan niệm của Đạo giáo về việc đề cao sự phát triển của vạn vật theo thuộc tính khách quan nhằm đáp ứng với môi trường mà nó sinh tồn.

Những ngọn núi, cánh rừng, đại dương, sông suối và các loài động - thực vật cõi thiên thai kêt hợp với nhau đã tạo nên một hệ sinh thái núi rừng nguyên sơ, gợi sự tò mò và niềm tin thấp thoáng nơi con người về một vùng đất, một hệ sinh thái thuần tự nhiên khoẻ mạnh có thật. Từ góc nhìn sinh thái, chúng tôi nhận thấy rằng thiên thai chính là biểu tượng về một khu rừng nguyên sinh với bộ gen xanh tươi, thuần khiết, được lưu giữ trong ký ức các cộng đồng. Con người vốn cũng từ thế giới nguyên thuỷ ấy mà bước ra, tuy nhiên, càng dấn thân vào con đường văn minh hoá, xa rời tự nhiên, con người càng ý thức được hệ lụy khủng khiếp từ thái độ và hành động quay lưng của mình. Những khi rơi vào khủng hoảng, bế tắc, con người lại tìm về với cội nguồn tự nhiên để tựa nương hoặc sống trong sự nuối tiếc những vẻ đẹp đã mất. Bởi vậy mà ta thấy hầu hết ở các sáng tác, sau khi lạc vào cõi tiên và trở lại trần gian, các nhân vật đều nỗ lực thực hiện hành trình quay trở lại kiếm tìm nhưng đều thất bại. Nó tạo thành một niềm day dứt, luyến tiếc, một ẩn ức cứ trở đi trở lại trong tâm thức của con người nói chung, trong sáng tác của các thi nhân trung đại nói riêng. Đó cũng là lý do vì sao khi đứng trước một cảnh thiên nhiên núi rừng hoang sơ, các thi nhân liền liên tưởng tới cõi thiên thai với hệ sinh thái nguyên thuỷ, thuần khiết, lặng lẽ và khát khao được vươn tới chốn non tiên. Họ đã dùng thơ ca để tái sinh tâm thức ấy. Tâm trạng này được thể hiện khá phổ biến trong thơ Trung Hoa và Việt Nam. 
Đào Uyên Minh khi được cáo quan trở về ẩn cư chốn nước biếc non xanh cũng tự thấy lòng hạnh phúc như con chim, con cá được trở về với nguồn cội. Trải nghiệm xa xưa đặc biệt ấy, ông không thể miêu tả hết được mà chỉ biết dùng văn chương để gợi lên những cảm xúc đồng vọng nơi người đọc: Thiếu vô thích tục vận/Tính bản ái khâu sơn/Ngộ lac trần võng trung/ Nhất khứ tam thập niên/ Ky điểu luyến cưu lâm/ Trì ngu tu cố uyên (Lúc trẻ không thích hùa theo thói tục/ Bản tính vốn yêu thích chốn núi sâu/ Trót lầm lạc trong lưới trần/ Một thoáng chốc đã ba mươi năm trời/ (Như) Con chim trong lồng nhớ rừng cũ/ (Như) Con cá trong ao nhó đầm cũ - Quy điền viên cu kỳ I). Lý Bạch - thi nhân tiêu biểu của dòng thơ du tiên Trung Hoa, khi đứng trước khung cảnh hoa đào trôi theo dòng nước giữa non xanh cô tịch, ông chỉ thấy tâm hồn như lạc vào một vùng trời đất không phải là ở chốn nhân gian. Trước câu hỏi "vì sao ta lại vào trong núi xanh" của người đời, ông cũng chỉ "cười mà không trả lời" (tiếu nhi bất đáp), chỉ biết nơi đó mang đến cho ông cảm giác thăng hoa nhẹ bẫng "tâm tự nhàn": Vấn $d u$ hà ý thê bich son/ Tiếu nhi bất đáp tâm tư nhàn/ Đào hoa lưu thuý diễu nhiên khúr/ Biệt hũu thiên địa phi nhân gian (Hỏi vì sao ta lại vào trong núi xanh/ Cười không trả lời mà lòng thấy tự nhàn/ Hoa đào trôi theo dòng nước và mất hút/ Cả một thế giới không phải là chốn nhân gian - Son trung vấn đáp). Không chỉ có Đào Uyên Minh, Lý Bạch, mà tâm thức tìm về với thiên nhiên hoang sơ của rừng suối, núi non, biển cả và khắc khoải trước tiếng gọi nơi cội nguồn sâu thẳm còn xuất hiện rất nhiều trong sáng tác của các ẩn sĩ đạo gia Trung Hoa như Giả Đảo, Tạ Diểu, Vương Hy Chi...

Trong văn học trung đại Việt Nam, hệ sinh thái nguyên sơ của thiên thai cũng không ngừng mời gọi, hấp dẫn các nhà văn, nhà thơ. Nhìn thấy một cảnh rừng già trên cao, hay một không gian sơn thuỷ bao la, hùng vĩ, như một lực hấp dẫn của quán tính tâm hồn, các thi nhân không khỏi rung động và liên tưởng tới cõi tiên thoát tục. Theo đó, khung cảnh chùa Thiên Thánh Hựu Quốc nằm chót vót nơi núi cao, giữa một sáng xuân tinh khôi đã đưa tâm hồn Nguyễn Phi Khanh lạc vào chốn Bồng Lai non xanh thuần khiết, trong veo, lay động khó tả: Tiên gia cung khuyết cận Bồng Lai/Nhĩ bạn quân thiên mộng dị hồi Thuy khởi xuân triêu vô cá sư/ Đông phong đình viện khán hoa khai (Cung điện thần tiên gần với cảnh Bồng Lai/ Nhạc trời ở bên tai nên giấc mộng dễ tỉnh/ Sáng xuân thức dậy không có việc gì làm/ Chỉ xem hoa nở trước gió xuân ở ngoài sân Thiên Thánh Hựu Quốc tư tảo khởi). Đứng trước chốn thiên nhiên mây trời, suối xanh, rừng cao với đủ chiều không gian rộng, sâu, xa, tâm hồn Trần Nguyên Đán cũng như được gột rửa sạch sẽ khỏi mọi bụi trần, hoà nhập cùng cõi hư huyền của vũ trụ bao la vô tận: Hạm tiền vân khi Bồng Lai viễn/Chẩm bạn tuyền thanh bich hán cao/ Thốn đoạn huyền quan phi kiếp thach/Trắc sinh hải vũ nhập thu hào (Mây tụ trước hiên, Bồng Lai xa thẳm/ Suối reo bên gối, trời xanh cao vời/ Tạm đóng cửa huyền lại để đi vào không gian vô tận/ Sống ghé trong hải vũ chỉ là bước vào chốn thu hào - Đề Sùng $H u$ lão túc). Nguyễn Trãi thì tìm thấy ở tiên cảnh núi Côn Sơn nơi ông ẩn cư ở một cuộc sống tự nhiên trong lành, tinh khiết như ngàn cây, ánh sáng và khí trời, được ngăn cách hoàn toàn với bụi trần bên ngoài: Tiên thu sổ quyển cưu sinh nha/ Co thực tùng căn tước nhật hoa/ Trúc hưu thiên can lan tục khách/Trần vô bán điểm đáo sơn gia (Mấy quyển sách tiên là vốn sinh nhai/ Đói ăn rễ thông và hớp ánh nắng/ Trúc có ngàn cây để ngăn khách tục/ Bụi không nửa hạt bén vào căn nhà trong núi - Hoạ hưu nhân yên hà ngụ hứng kỳ III). Tương tự như vậy, Vũ Vĩnh Trinh, Nguyễn Trung Ngạn cũng tìm thấy sự giao hoà giữa cái sâu thẳm của của thiên nhiên với cái chiều hư trong tâm hồn (Đăng Yên Phu sơn), cái hùng vĩ tráng lệ của sơn thuỷ với cái khoáng đạt của con người (Thần Phù cảng khẩu hiểu bac)... để rồi trong khoảnh khắc, các thi nhân như hoá vào cõi tiên cảnh thuần khiết, trong trẻo. Cũng nhờ vậy mà tâm hồn họ đạt được trạng thái an nhiên, ung dung, tự tại.

Có thể thấy, tâm thức hoà mình vào thiên nhiên nguyên sơ để tìm thấy chính tâm hồn và bản thể tự nhiên của mình, để gột hết bụi trần mà 'phi thăng thành tiên" đã được các thi sĩ, văn nhân Việt Nam nhận diện và giải phóng một cách tối đa trong thơ văn. Tự nhiên rừng núi, sông biển đã trở thành vũ trụ hiền từ nuôi dưỡng, giáo dục nhân cách và trở thành đích đến của đời sống con người. Đó cũng là con đường "quy hồi bản nhiên", quay về và tìm ra cái bản thể, gốc rễ tự nhiên trong căn tính nhân loại (Lưu Hồng Sơn, 2014) . Vì vậy, xu hướng khát khao kiếm tìm, hướng về tự nhiên để hoà vào tự nhiên là một tất yếu của tâm thức con người. Nó đã được các thi nhân phản ánh một cách lãng mạn, bay bổng qua biểu tượng thiên thai trung đại.

\subsection{Biểu tượng thiên thai - nơi con người học cách thích nghi với tự nhiên}

Sau một quá trình dài mang tư tưởng con người trung tâm để đối xử với tự nhiên một cách thô bạo thì đến những năm 80 của thế kỷ XX, tinh thần đề cao sinh thái và lối sống thích nghi với tự nhiên chốn đồng quê đã được người phương Tây thực sự chú trọng. Văn học sinh thái, đặc biệt là dòng văn học 
đồng quê (pastoral literature) đã ra đời và bùng nổ cùng những cái tên tiêu biểu như Margaret Atwood với tác phẩm Nổi lên bề mặt (Rise to the surface), Jean Hegla với tác phẩm Vào rùng (Go to the forest)... Thông điệp chung mà các nhà văn này đưa ra là kêu gọi con người hướng về tự nhiên và cuộc sống nông nghiệp lý tưởng chốn nông thôn để hàn gắn vết thương sau những va đập với cuộc sống văn minh thị thành. Nhưng không phải chờ đến mãi thế kỷ XX như phương Tây, người phương Đông từ rất sớm đã nhìn thấy "lỗ hổng" sinh thái do mình tạo ra và thiết lập cách cân bằng sinh thái qua việc: bảo lưu hình thức sinh hoạt nông nghiệp của đời sống nguyên thuỷ cổ xưa. Dựa trên mục đích đó, có thể xác định "tiểu quốc quả dân" xuất hiện trong Đạo đức kinh của Lão Tử từ rất sớm (thế kỷ thứ IV trước công nguyên) là một "hạt nhân", được khái quát bằng hai yếu tố chính: Một là nước nhỏ, dân ít; hai là đời sống nông nghiệp giản đơn với nhu cầu tối giản như ăn chỉ cần no, mặc chỉ cần ấm, ở chỉ cần yên, sống chỉ cần vui, chăn nuôi gà chó, bỏ hết văn tự, không sử dụng khí cụ, không xâm phạm lẫn nhau. Đối chiếu từ góc nhìn của sinh thái học hiện đại, mô hình sống này rất tích cực, bởi nó hạn chế được tối đa sức ép của dân số và tác động của văn minh nhân loại lên môi trường sống tự nhiên. Trên tinh thần đề cao sinh thái của người phương Đông cổ xưa, mô hình "tiểu quốc quả dân" của Lão Tử nhằm mong muốn con người quay trở về lối sống tự nhiên "vô vi", "vô dục", "phản phục", tức là không làm gì trái với luật tự nhiên của vũ trụ, không ham muốn cái gì ngoài những nhu cầu tối thiểu tự nhiên của con người, quay trở về với lối sống giản đơn, thuận theo tự nhiên. Lời kêu gọi này của Lão Tử đã nhận được sự đồng tình của học trò mình là Liệt Tử, Trang Tử và về sau này là các ẩn sĩ Đạo gia thông qua việc xây dựng một mô hình xã hội - sinh thái lý tưởng gắn liền với biểu tượng thiên thai.

Trong văn xuôi, đặc biệt là ở các truyện truyền kỳ, dấu ấn của tinh thần sinh thái theo tư tưởng Đạo gia được thể hiện khá rõ nét, từ Luu Nguyễn nhập Thiên Thai của Can Bảo cho tới Đào hoa nguyên ký của Đào Uyên Minh, rồi Thiên Thai phỏng ẩn luc của Cù Tông Cát.... Bên cạnh hình ảnh những núi non rừng suối nguyên sơ, ta luôn thấy thấp thoáng dấu ấn về một môi trường nông nghiệp khép kín bằng cuộc sống tự cấp tự túc, nương tựa hầu như hoàn toàn vào sự dưỡng nuôi và bảo vệ từ mẹ thiên nhiên của cộng đồng thời nguyên thuỷ. Đào hoa nguyên ký có thể được coi là sáng tác chứa đựng mô hình sinh thái nông nghiệp gắn với đào nguyên, thiên thai được hoàn chỉnh hoá sớm nhất. Nếu trong "tiểu quốc quả dân" của Lão Tử, mô hình sinh thái nông nghiệp còn chưa được thể hiện rõ nét thì trong sáng tác của Đào Uyên Minh, nó đã được văn nhân cụ thể hoá trên ba yếu tố chính: không gian, hệ thực - động vật trong thế gắn liền với con người. Trong thơ ca, Đào Uyên Minh cũng là văn nhân sớm nhất, tích cực nhất trong việc đề cao lối sống thuận theo tự nhiên và là người tiên phong trong việc sáng tạo, bổ sung vào mô hình sinh thái nông nghiệp cõi thiên thai những yếu tố không gian thiên nhiên như bãi bờ, đồng ruộng, ao bể, suối mát... Cùng với đó, ông liên tục đưa ra lời kêu gọi con người sống thuận tự nhiên như một tiếng đồng vọng thiết tha với tiền nhân trên tinh thần "quy hồi bản nhiên": Cẩu phệ thâm hang trung/Kê minh tang thu điên/ Hộ đình vô trần tạp/ Hu thất hũu du nhàn/Cửu tại phiền lung lý/ Phục đắc phản tụ nhiên (Ngõ sâu chó sủa vọng/ Ngọn dâu gà gáy dài/ Sân ngoài không mảy bụi/ Nhà rỗng thừa thảnh thơi/ Cũi lồng sao bó mãi/ Quay về với tự nhiên - Quy viên điền cu kỳ I, do Truơng Việt Linh dịch). Sau Đào Uyên Minh, nhiều sáng tác của thi nhân Trung Hoa, Hàn Quốc như Vương Duy (với Đào nguyên hành), Nhân Lão (với Hoa quy khứ lai tùi)... cũng đều gắn liền thiên thai với "mô hình xanh" như vậy. Không chỉ đề cao việc sống hài hoà với tự nhiên, bảo lưu mô hình sinh hoạt của cộng đồng nguyên thuỷ mà trên cơ sở tinh thần Lão Trang, các văn nhân còn tiến tới phát triển mô hình nông nghiệp ấy dựa trên các yếu tố cụ thể là không gian, hệ thực vật - động vật và con nguời nông nghiẹpp.

Từ văn học Trung Hoa, các văn nhân trung đại Việt Nam đã hấp thu và sáng tạo mô hình sinh thái nông nghiệp đó trong các sáng tác của mình. Trong rất nhiều tác phẩm, hễ cứ xây dựng cảnh thiên thai, đào nguyên, tiên cảnh là các tác giả lại gắn liền nó với môi sinh xanh tươi lý tưởng này. Cao Bá Quát là một văn nhân tiêu biểu trong việc xây dựng chốn đào nguyên mang bóng dáng nông nghiệp, làng quê theo tinh thần cổ nhân. Đào hoa nguyên lý nhân gia là tác phẩm tiêu biểu cho tinh thần ây: Tiên gia cọng kết thôn/Đường tiền nhung nguyệt đáo/ Động khẩu để vân đồn/Tái phỏng tri vô lộ/Thôi tà bất đáo môn/ Độ niên vong Tấn Nguy/ Khoản khách hưu kê đồn/ Tư lãng tha huoong diê̂̀m/ Hồng trần cách lộ huyên (Nhà tiên kết lại thành thôn xóm/ Trước sân vầng trăng lại sáng/Cửa động từng lớp mây dồn/Lại thăm mà không biết lối/ Chiều xuống quay lại không thấy cửa/ Nhiều năm nên không biết đến thời Tấn Nguỵ/ Đãi khách sẵn có gà lợn/ Sóng nước tím đưa hương thơm ngát/ Cách xa đường lớn đầy bụi bặm ồn ào). Dù vậy, ở những câu thơ cuối, hình ảnh: hoa nở rụng (hoa khai lac) và tâm thế lặng lẽ chẳng nói gì (thành hề tổng bất ngôn) lại gợi lên trong tứ thơ bóng dáng 
một con người với vòng tâm trạng luẩn quẩn, cô đơn, đầy tâm sự, dù đã vào cõi đào nguyên, tiên cảnh mà lòng vẫn mang nặng nỗi ưu tư khôn nguôi hướng về trần gian, quê cũ.

Ngược lại với Cao Bá Quát, chốn đào nguyên trong Lâm tuyền vãn (còn gọi là Đào nguyên hành) của Phùng Khắc Khoan cũng là một mô hình sinh thái đào nguyên hoàn chỉnh gắn liền với sinh hoạt nông nghiệp, nhưng lại được hoà thể trong niềm vui say sưa, giọng điệu hóm hỉnh của thi nhân. Bài thơ được coi là một bản trường ca gồm 185 câu thơ lục bát chữ Nôm đầy sáng tạo về con người và thiên nhiên, trong sự lắng đọng của mạch nguồn dân gian, dân tộc. Ở nơi đó, con người hoà vào cuộc sống của một lão nông tri điền với dăm mẫu vườn tràn đầy cỏ hoa: Chọn nơi đất rộng trống không/Mở vườn dăm mẫu vun trồng cỏ hoa. Từ bàn tay khéo léo và tâm hồn yêu quý cỏ cây, yêu cuộc sống thôn quê của con người, một mảnh vườn sum suê với đủ các loại thực vật như dâu, gai, đậu sừng, mướp, dưa chuột... cùng những ao cá, phên dậu ra đời. Không chỉ vui vầy với việc trồng trọt trên mảnh vườn yêu dấu mà con người còn tích cực chăn nuôi, sản xuất trong niềm vui bội thu: Trâu bò gà lơn dê ngan/Đầy lũ đầy đàn thả khắp mọi nơi. Tâm thế của lão nông - thi nhân luôn hiện lên với vẻ khoan khoái, hứng khởi khi được hoà mình vào cuộc sống ấy. Trong hoàn cảnh bị triều đình lưu đày, Phùng Khắc Khoan đã biến rừng suối - chốn lưu đày thành đào nguyên - chốn thôn quê nông nhàn vui tươi, đủ đầy, mang đậm bản sắc, hương vị của làng quê Việt. Ở đó, thi nhân như một bậc thần tiên với tâm hồn tự do tự tại, hoà nhập tối đa vào môi sinh xanh tươi đầy sức sống của nông thôn bằng tinh thần lạc quan tích cực của một Nho sĩ ở "ngoài vòng" danh lợi: Vô sư là tiểu thần tiên/ Gẫm xem ngoại thú lâm tuyền cực vui!

Không u uất như Cao Bá Quát, cũng không hóm hỉnh, lạc quan như Phùng Khắc Khoan, Nguyê̂̃n Du cũng hướng tới xây dựng cõi thiên thai trên cơ sở tư tưởng của tiền nhân, song mô hình sinh thái nông nghiệp của ông ở Son thôn là một mô hình sống động, được thể hiện một cách cô đọng, súc tích mà đầy lãng mạn, ý vị chỉ trong hai câu thơ: $M u c$ nhi chuỳ giác hoang giao mô/ Cấp nũ liên đồng ngọc tỉnh xuân (Trong ánh chiều tà, trẻ chăn trâu gõ sừng trên đồng hoang/ Giữa ngày xuân, cô gái nối ống bương dẫn nước từ giếng ngọc). Qua ngòi bút của thi nhân, chốn đào nguyên nơi núi sâu không hoang vu, vắng lặng mà thật dân dã, thân quen với hình ảnh làng quê ấm áp, nơi con người sống thật giản dị, hài hoà, thuần khiết cùng tự nhiên. Cảnh đào nguyên ở cõi trần đậm màu sắc chốn nông thôn bình dị, nơi con người sống hài hoà cùng cuộc sống nông nghiệp mang tính chất mùa vụ nhẹ nhàng còn trở lại một lần nữa trong thơ Nguyễn Du ở Hoàng Mai sơn thuợng thôn hay Ngã Khán Vu Lai của Ngô Thế Lân. Ở đó, con người thuần hậu, chăm chỉ, gắn bó với hoạt động nông nghiệp thuần nguyên, không quan tâm chuyện thời thế bên ngoài nên đời sống vui tươi, tuổi thọ kéo dài.

Tâm thức hướng tới cõi đào nguyên, tiên cảnh cùng mô hình sinh thái nông nghiệp xanh tươi, lành mạnh dường như đã ăn sâu vào tâm khảm của các thi nhân. Tuy nhiên, ngoài việc tích cực xây dựng và bảo lưu mô hình sinh thái nông nghiệp gắn liền với thiên thai, cõi tiên, tâm thức ấy còn dẫn tới một hệ quả khác, đó là việc các thi nhân khi đứng trước khung cảnh nông thôn, làng quê, nơi con người sống hài hoà, thích nghi với tự nhiên cùng thửa ruộng, cánh đồng, dòng sông, ao bãi, khu vườn là liền liên tưởng, so sánh, ví von với cảnh đào nguyên, thiên thai. Tiêu biểu là thi nhân Thái Thuận với Hoàng Giang tức cảnh. Bài thơ gợi lên hình ảnh dòng sông Hoàng Giang mênh mông rợn ngợp bốn bề triều dâng, cuộc sống con người hiện ra trong thế tựa nương vào thiên nhiên với những ánh đèn, ruộng đồng, những ngôi nhà xa gần thấp thoáng: Chiếu dã đăng minh gia viễn cận/ Mạn thiên triều tướng thuỷ tây đông (Đèn sáng soi đồng nội, nhà xa nhà gần thấp thoáng/ Triều dâng ngút trời, phía đông phía tây đều có nước tràn). Cả một vùng cảnh vật thôn quê: dòng sông, con thuyền, lau sậy, cò vạc bao trùm bởi ánh trăng trải dài và tiếng sáo thoảng bay đầy êm đềm, trong trẻo đã nâng cánh tâm hồn của con người, khiến thi nhân cảm thấy như đang bay bổng vào cõi tiên diệu huyền: Khách chẩm dạ thâm phương tựu thuỵ/ Tam canh phi mộng đáo thiên cung (Đêm khuya gối khách vùa mói êm giấcl Khoảng canh ba, hồn mộng đã bay đến cung trời). Cùng tâm thức đó, Ngô Thì Nhậm khi viết Mộng Thiên Thai phú cũng đã ngợi ca cuộc sống nông thôn làng quê của mình. Dưới ngòi bút của thi nhân, thiên thai không còn là cõi tiên xa xôi, vắng vẻ, cách biệt trần thế như trong truyền thuyết mà nó chính là hình ảnh làng quê ở "ngọ̣ Đông Cửu hạt Gia Định lừng tiếng miền Giang Bắc" và toả lên hơi ấm của sự sống con người với những sinh hoạt đơn sơ nơi chợ búa, xóm làng, ruộng đồng, nương dâu: Gián yên hà ư thổ thạch/ Ân tang ma hồ tùng trúc/ Tả triền mạch nhi hữu lưu diêm/ Giang nguyên diền nhi trắc pha lộc (Núi đá lẫn khói mây/ Dâu gai xen tùng trúc/ Lối chợ, bên trái quanh/Xóm làng bên phải moc/ Bước xuống: ruộng với đồng/Trèo lên: gò với dốc). Khao khát hướng về cõi thiên thai đã hoà vào tâm hồn luôn hướng về thiên nhiên làng cảnh quê hương của Thái Thuận, Ngô Thì Nhậm. Đồng thời, nó cũng cho thấy 
tinh thần hướng về tự nhiên, hoà vào tự nhiên vốn là bản năng thường trực trong trái tim đầy nhạy cảm của người nghệ sĩ.

Những phân tích trên cho thấy mô hình sinh thái nông nghiệp trong sáng tác của các thi nhân mang vẻ đẹp hoà quyện của tự nhiên và đời sống con người. Ở đó, tự nhiên vẫn giữ vai trò chủ đạo, con người thấp thoáng hiện lên trong thế tựa nương vào tự nhiên ở cả góc độ vật chất lẫn tinh thần. Đặc biệt, khi đi vào thi ca Việt Nam, tính khuôn mẫu của bút pháp ước lệ trung đại đã được giảm bớt, thay vào đó, các thi nhân tích cực đưa vào mô hình sinh thái của mình những hình ảnh thiên nhiên thanh bình gắn liền với làng xóm, quê hương. Ở nơi đó, ruộng đồng, vườn ao, cỏ cây, hoa lá hiện lên trong thế đối lập với "vòng thế tục", với chốn "bụi trần", "lao xao", "ồn ào" đầy thị phi, tranh đấu và trở thành mảnh đất nương náu cho tâm hồn con người trong cơn gió bụi kinh thành. Tâm thức hướng về cội nguồn, quê hương đã gặp gỡ, hoà quyện với tâm thức hướng về tự nhiên của thi nhân nói riêng, của người phương Đông nói chung. Tự nhiên, làng quê do đó trở thành mái nhà không dễ gì rời xa và nếu có đi xa thì đó cũng là nơi mà con người luôn muốn quay trở về, dừng chân nghỉ ngơi, sống những ngày tháng êm đềm như Nguyễn Du đã khẳng định: Ná đắc khiêu ly phù thế ngoại/ Truờng tùng thụ hạ tối nghi nhân (Mong sao được vượt ra ngoài vòng thế tục/ Thì dưới hàng thông cây cao bóng cả kia là nơi rất thích hợp - Son thôn). Đây chính là một quy luật sống xuất phát từ quy luật tâm hồn của nhân loại.

\section{KẾT LUẬN}

Trên cơ sở tư tưởng Lão - Trang, một triết thuyết cổ xưa in đậm dấu ấn tâm hồn và trí tuệ sinh thái phương Đông, các tác giả trung đại Trung Hoa và
Việt Nam đã đưa cõi thiên thai trở thành biểu tượng chứa đựng tinh thần sinh thái. Cụ thể, đó là tinh thần sùng thượng tự nhiên gắn liền với việc lưu giữ một môi trường tự nhiên nguyên sinh và bảo lưu một mô hình sinh hoạt nông nghiệp cổ xưa độc đáo. Bên cạnh đó, các văn nhân cũng luôn nỗ lực thực hiện những cuộc hành trình trở về với tự nhiên thuẩn khiết, với cội nguồn sống trong sự khắc khoải tìm lại những vẻ đẹp xa xưa, những cảm xúc nguyên thuỷ còn lưu giữ trong vô thức của cộng đồng. Điều đặc biệt là tất cả những nỗ lực xây dựng mối quan hệ hài hoà giữa con người và tự nhiên, cũng như những trải nghiệm lãng mạn, bay bổng ấy đã được các văn nhân trung đại chuyển hoá, kết tinh ở biểu tượng thiên thai. Đứng trước những hậu quả nặng nề của việc tàn phá môi trường tự nhiên mà con người để lại ngày hôm nay, soi mình vào những giá trị văn học cổ xưa, chúng ta càng thêm ý thức về vai trò, trách nhiệm của mỗi cá nhân trong việc bảo vệ tự nhiên và bảo lưu những giá trị tinh thần quý báu mà tiền nhân đã để lại.

\section{TÀI LIÊU THAM KHẢO}

Lão Tử. (2021). Đạo đức kinh. (Nguyễn Hiến Lê dịch và chú giải). Nhà xuất bản Hồng Đức.

Lưu Hồng Sơn. (2014). Đào nguyên - Thế giới tâm linh của văn nhân Đông Á. Tạp chí Nghiên cứu văn hoc, 1, $22-36$.

Nguyễn Kim Châu. (2020). Văn học cổ Việt Nam và Trung Hoa: Những hướng tiếp cận. Nhà xuất bản Tổng hợp thành phố Hồ Chí Minh.

Trang Tử. (2021). Nam hoa kinh. (Nguyễn Hiến Lê dịch và chú giải). Nhà xuất bản Hồng Đức.

Trần Trúc Lâm. (2013). Đầu xuân nói chuyện thiên thai.

http://phatgiaobaclieu.com/dau-xuan-noi-chuyenthien-thai-tran-truc-lam/ 